\title{
Problems Associated with the Use of Internet Facilities among Rural Farmers and Extension Workers in Benue State
}

\section{Gyata, B.A. ${ }^{1}$, Obinne, C.P.O. ${ }^{2}$ and Age, I.A. ${ }^{2}$}

1. Department of Agricultural Education, College of Education, Katsina-Ala, Benue State, Nigeria. bgyata@yahoo.com 07030178706

2. Department of Agricultural Extension and Communication, University of Agriculture, Makurdi, Benue State, Nigeria.

\section{Abstract}

The survey was conducted in Benue State to analyze the major problems associated with the use of Internet facilities. The population of this study consisted of all rural farmers and extension workers in the study area. However, a sample size of 193 respondents was selected using purposive, snow ball and simple random techniques. Data for this study were collected mainly from primary sources, through the use of a well structured questionnaire along-side interview technique. The data collected were analyzed using descriptive statistics such as frequency and percentages as well as inferential statistics such as factor analysis. It was found that, high cost of computers HCOC $\left(0.905^{*}\right)$, high cost of air time HCOA $\left(0.881^{*}\right)$ and lack of skills and knowledge LOSK $\left(0.854^{*}\right)$, were the socio-economic factors that affected respondents in the use of internet facilities. Others such as lack of awareness of existence of internet facilities LAEI $\left(0.932^{* *}\right)$, lack of internet facilities LIF $\left(0.905^{* *}\right)$ and inadequate network IANW $\left(0.926^{* *}\right)$ and so on were the infrastructural factors that affected respondents. It is recommended that, government should collaborate with other stake holders with a view to putting in place, a legal and institutional framework which will enhance a full take off of the internet usage among farmers and extension workers.

Key words: Internet Facilities, Rural Farmers, Extension Workers.

\section{Introduction}

An important objective of agricultural extension is to improve the productivity of rural farmers so as to promote food-self-sufficiency and food security among the rural farmers (Ogunbameru, B.O; Udiandege, U.C. and Ani, A.O, 2008). An integral part of extension work is communication; but communication is only said to be effective when there is meaningful sharing of experiences among the participants.

The productivity of local farmers has often been affected by the inability to get and share relevant and timely information concerning farming activities. This is in addition to the rate at which available research results are lost (Alao, 1980). To crown it all, there is a lag of about 50 years between discovery of new farming practices and their utilization in the field (Ogunfowora, 1981) as cited by Ayichi (1995). From the foregoing, one can observe that there is a weak research-farmer linkage and this linkage is extension service.

The inefficiency of extension service in passing information to farmers is extremely difficult due to the type of channels used to send the information across to the clientele and their seemingly inadequacy in number. At present, Benue Agricultural and Rural Development Authority (BNARDA), for instance, requires 368 village extension agents (VEAs). However, only 98 VEAs are employed. Most times, handbills are printed but could not reach most of the audience because the handbills might not go round the places. 
It is hoped that information and communication technologies (ICTs) will provide both "new and unique opportunities of effectively providing farmers with timely information, when and where it is needed" (Arokoyo, 2008).

According to Rodriguez and Wilson (2000), the World Bank defines ICTs as "The set of activities which facilitate by electronic means the processing, transmission and display of information. Odiaka (2011) states that, ICTs are greatly influencing people's life in every aspect of the social, economic and political endeavors.

There is a critical need for the innovative use of ICTs to transform agricultural extension for sustainable participatory development (Arokoyo, 2008). One tool that can serve this purpose is the Internet. Gyata and Obinne (2012) suggested that farmers should be adequately trained by the relevant agencies to enhance the adoption and efficient use of technologies especially in the area of ICT. This will go a long way in achieving the current agricultural transformation agenda (ATA) of the Federal government. This is possible because many farmers now use the handset and are literate including degree holders.

\section{Purpose of the Study}

The broad objective of this study was to analyze the problems associated with the use of Internet facilities among rural farmers and extension workers in Benue State. Specifically, the objectives of this study were to:

i. identify the existing ICTs and usage; and

ii. determine problems militating against the use of Internet facilities among rural farmers and extension agents

\section{Methodology}

The study was carried out in Benue State. Presently, Benue State has twenty three local government areas, with a land mass of 33,955 square kilometers and lies between latitudes $6.50^{\circ}$ and $8.80^{\circ}$ North and longitudes $7.47^{\circ} \mathrm{N}$ and $10.00^{\circ}$ East (Benue State Government, 2012). The ecology of Benue State supports extensive arable crop and livestock production as well as fruit, palm, grains, legumes, root and tuber production. Benue State has a population of $4,253,641$ (Gazette, 2009). Over 80 percent of this population derives its livelihood from agriculture with more than 70 percent of the populace living in the rural areas.

The population of this study consisted of all farmers in Benue State and all extension staff of Benue State Agricultural and Rural Development Authority (BNARDA). A total of one hundred and ninety three respondents were selected. Firstly, two agro-ecological or agro-development zones (Eastern and Northern) were purposively selected due to their high agricultural productivity within the state. In each zone, two local government areas (a total of four) were purposively selected. Again, in each LGA, two settlement areas were purposively selected due to their high agricultural productivity and their geographical spread within the LGA. Using stratified/proportional allocation, $5 \%$ of the sample frames of farm families and $50 \%$ of extension workers were randomly selected using simple random sampling techniques.

The variables measured were, age, sex, marital status, level of education, annual income, availability and utilization of ICT facilities and problems faced by respondents. 
Table 1: Sample size selection

\begin{tabular}{|c|c|c|c|c|c|}
\hline $\mathbf{S} / \mathbf{N}$ & $\begin{array}{c}\text { Agro-Ecological } \\
\text { Zone }\end{array}$ & L. G. A. & $\begin{array}{l}\text { Settlement } \\
\text { Area }\end{array}$ & $\begin{array}{l}\text { Sample Frame } \\
\text { of Farm Family }\end{array}$ & $\begin{array}{l}\text { Sample Size } \\
\text { Selection } \\
(5 \%)\end{array}$ \\
\hline 1 & Eastern Zone & $\begin{array}{c}\text { Ukum } \\
\text { Katsina-Ala }\end{array}$ & $\begin{array}{c}\text { Ayati } \\
\text { Afia } \\
\text { Sati } \\
\text { Sai }\end{array}$ & $\begin{array}{l}741 \\
519 \\
320 \\
680\end{array}$ & $\begin{array}{l}37 \\
26 \\
16 \\
34\end{array}$ \\
\hline 2 & Northern Zone & $\begin{array}{l}\text { Gboko } \\
\text { Guma }\end{array}$ & $\begin{array}{l}\text { Ikyungur } \\
\text { Amaladu } \\
\text { Gbajimba } \\
\text { Daudu }\end{array}$ & $\begin{array}{l}250 \\
170 \\
320 \\
180\end{array}$ & $\begin{array}{c}13 \\
9 \\
16 \\
9\end{array}$ \\
\hline & Sub-Total & & \multicolumn{2}{|c|}{$\begin{array}{c}3180 \\
\text { Sample Frame of VEA }\end{array}$} & $\begin{array}{c}159 \\
\text { Sample Size } \\
\text { Selection } \\
(50 \%)\end{array}$ \\
\hline 3 & Eastern Zone & $\begin{array}{l}\text { Ukum } \\
\text { Katsina-Ala }\end{array}$ & & $\begin{array}{l}18 \\
16\end{array}$ & $\begin{array}{l}9 \\
8\end{array}$ \\
\hline 4 & $\begin{array}{c}\text { Northern Zone } \\
\text { Sub-Total } \\
\text { Grand Total }\end{array}$ & $\begin{array}{l}\text { Gboko } \\
\text { Guma }\end{array}$ & & $\begin{array}{c}20 \\
14 \\
68 \\
3248\end{array}$ & $\begin{array}{c}10 \\
7 \\
34 \\
193\end{array}$ \\
\hline
\end{tabular}

Source: Adapted From NPC (1991) Projected to 2012

Primary data were collected with the use of a structured questionnaire and interview schedule. Data were analyzed using both descriptive statistics including factor analysis. The Rtype approach was used and variables with coefficients of 0.30 or more (Kaiser's rule of thumb) were used in naming a factor.

\section{Results and Discussion}

\section{Socio-Economic Characteristics}

Table 2 reveals that $75.60 \%$ of the respondents were in the productive age category of 21-50 years, meaning that they were youthful, active and yet mature. It also shows that there were $72.50 \%$ male and $27.50 \%$ female. Although, this result shows a significantly higher number of male respondents, it will not affect the adoption of the use of Internet in communicating agricultural problems/solutions, since resource-poor men and women farmers do not differ significantly in their rate of adoption of innovations (Agbaerevo, 2007). The table shows that, majority $(67.40 \%)$ respondents were married and still staying with their spouses.

Majority $(38.30 \%)$ of the respondents attended tertiary institutions other than the University. This was followed with $29.00 \%$ of the respondents who attended and obtained the Senior Secondary School Certificate (SSCE). This result confirms a priori expectation that extension agents and some rural farmers are literate enough to adopt ICTs.

The highest number $(48.20 \%)$ of the respondents earned an average income of between N 101,000= and $\mathrm{N} 450,000=$ per annum, this is followed by $28.00 \%$ of the respondents who earned less than $\mathrm{N} 101,000=$ per annum. The remaining $23.80 \%$ earned more than N $450,000=$ per annum. Those respondents (23.80\%) who earn more than $N-450,000=$ per annum are likely to be extension workers while those who earn less than $\mathrm{N}$ $101,000=$ per annum are likely to be rural farmers. The implications of the result to this study is that, given the right orientation, farmers/extension agents will be willing and able 
to at least pay for and use certain ICTs if convinced that this will actually lead to an improvement in their productivity.

Table 2: Distribution of the respondents based on socio-economic characteristics

Socio-Economic Variables $\quad$ Percentage $(\%)(n=193)$

\begin{tabular}{ll}
\hline Age years & 3.10 \\
$\leq 20$ & 20.20 \\
$21-30$ & 26.40 \\
$31-40$ & 29.00 \\
$41-50$ & 14.50 \\
$51-60$ & 6.80 \\
$>60$ & 100.00 \\
Sub-total (a) & \\
Sex & 72.50 \\
Male & 27.50 \\
Female & 100.00 \\
Sub-total (b) & \\
Marital status & 13.00 \\
Single & 67.40 \\
Married & 10.90 \\
Widow & 3.60 \\
Widower & 2.00 \\
Divorce & 3.10 \\
Divorcee & 100.00 \\
Sub-total (c) & \\
Highest level of Education & 13.00 \\
Non-formal & 15.60 \\
Primary Education & 29.00 \\
Secondary Education & 38.30 \\
Tertiary Education & 3.60 \\
University Education & 0.50 \\
Postgraduate Education & 100.00 \\
Sub -total (d) & \\
Average annual income (N) & 28.00 \\
s101,000 & 48.20 \\
101,000-450,000 & 23.80 \\
Sub,000 & 100.00 \\
\hline Sour-total (e) &
\end{tabular}

Source: Field Survey, 2012

\section{Availability and Level of Utilization of ICT Facilities}

Table 3 shows that the $100.00 \%$ of farmers had radios in their localities. Also all $(100.00 \%)$ the extension agents indicated that there were radios in their localities. Majority (97.50\%) of the farmers agreed that there was GSM in their localities; a closer percentage of $91.20 \%$ of the extension agents indicated the same. Again $93.71 \%$ and $100.00 \%$ of rural farmers and extension agents respectively indicated that there were television sets in their localities. Other ICT facilities available as indicated by both the rural farmers and extension agents included VCD/VCR $(73.00 \%$ and $94.10 \%$, respectively), newspaper/magazine $(56.00 \%$ and $76.50 \%$, respectively). Computers $(34.00 \%$ and $55.90 \%$, respectively) and the Internet had the least proportion of respondents with $28.90 \%$ of rural farmers and $53.90 \%$ of extension agents. 
On the use of ICT facilities $85.50 \%$ of the rural farmers indicated that they used GSM while $91.20 \%$ of the extension agents agreed that they used GSM. Again, while $69.20 \%$ of the rural farmers indicated that they used radio, $85.30 \%$ of extension agents used radio. Another $63.50 \%$ of rural farmers used television, while $73.50 \%$ of extension agents used television.Other ICT facilities used by the rural farmers and extension agents were; VCD/VRS (44. $70 \%$ and $64.70 \%$, respectively), newspaper/magazine $(28.30 \%$ and $70.60 \%$, respectively), Internet $(28.90 \%$, and $35.30 \%$, respectively), computer $(11.90 \%$ and $14.70 \%$, respectively) and satellite $(6.90 \%$ and $38.20 \%$, respectively).

The results confirm apriori expectation that the use of ICT facilities was higher among extension agents than rural farmers. This may be because of their level of education and income status. This implies that extension agents can also be used in the dissemination of information about and adoption of internet among farmers in Benue State. This result also implies that rural farmers can also adopt internet if they are properly educated.

Similarly, Aroyoko (2003) stated that "access to radio is extensive compared to any other ICTs with 4 in 10 persons living in the rural areas possessing radio". In this study, although, $100.00 \%$ respondents agreed that radios existed in their localities, higher than GSMs $96.37 \%$, the current GSM usage is higher (84.56\%), than radio's $72.02 \%$. The difference may be due to time. During this time (2003), GSM was not fully operational in the rural areas. This result also agrees with Akpantaku, and Lawal-Adebowale (2009). In their study of ICT status of agricultural research and extension organizations in southwestern Nigeria, the researchers reported that, all (100.00\%) extension organizations used radio but only $50.00 \%$ used the Internet. Also, a baseline study of ICT by the National Information and Telecommunication Development Agency (NITDA) (2003) reported that GSM phones were the most widely used means of communication in Nigeria. This result again is in consonance with the study carried out in Nigeria and published in The Punch (2006), cited in Salawu (2008) that very few Nigerians were having access to Internet services and that the use of Internet in Nigeria had been largely elitist as it was mostly used by the urban working class and students. 
Table 3: Distribution of respondents based on availability and level of utilization of ICT facilities

\begin{tabular}{|c|c|c|c|}
\hline $\begin{array}{l}\text { ICT Facilities } \\
\text { Available (a) }\end{array}$ & $\begin{array}{l}\text { Farmers } \\
\text { Percentage } \\
(n=159)\end{array}$ & $\begin{array}{l}\text { Extension } \\
\text { Workers } \\
\text { Percentage } \\
(n=34)\end{array}$ & $\begin{array}{l}\text { Farmers and } \\
\text { Extension } \\
\text { Workers } \\
\text { Percentage( } n=19 \\
\text { 3) }\end{array}$ \\
\hline Radio & 100.00 & 100.00 & 100.00 \\
\hline GSM & 97.00 & 91.20 & 96.40 \\
\hline Television & 93.71 & 100.00 & 94.80 \\
\hline VCD/VCR & 73.00 & 94.10 & 76.70 \\
\hline \multicolumn{4}{|l|}{ Newspaper/Magazi } \\
\hline ne & 56.00 & 76.50 & 59.60 \\
\hline Satellites & 46.50 & 58.80 & 48.70 \\
\hline Computer & 34.00 & 55.90 & 37.80 \\
\hline Internet & 28.90 & 53.90 & 33.20 \\
\hline \multicolumn{4}{|l|}{ ICT Facilities Used (b) } \\
\hline GSM & 85.50 & 91.20 & 84.50 \\
\hline Radio & 69.20 & 85.30 & 72.00 \\
\hline Television & 63.50 & 73.50 & 65.20 \\
\hline VCD/VCR & 44.70 & 64.70 & 48.20 \\
\hline \multicolumn{4}{|l|}{ Newspaper/Magazi } \\
\hline ne & 28.30 & 70.60 & 35.80 \\
\hline Internet & 28.90 & 35.30 & 35.20 \\
\hline Computer & 11.90 & 14.70 & 12.40 \\
\hline Satellites & 6.90 & 38.20 & 12.40 \\
\hline
\end{tabular}

Source: Field Survey, (2012)

${ }^{*}$ Multiple responses

\section{Factor Analysis of the Problems Faced by Farmers and Extension Workers in the Use of Internet Facilities}

Table 3 shows that there are two major categories of factors that are faced by farmers and extension workers in the use of Internet facilities namely, factor 1 and factor 2. Factor 1 is simply described as socio-economic factors while factor 2 is described as infrastructural factors. Factors with loadings of .3 and above (Kaiser's rule of thumb) were considered to constitute constraints to the use of Internet facilities by farmers and extension workers.

Consequently, the socio-economic variables considered as problems are; high cost of computer/modern HCOC $\left(.905^{\star}\right)$, high cost of airtime HCOAT $\left(.881^{\star}\right)$ and lack of skills and knowledge LOSK $\left(.854^{*}\right)$. The infrastructural variables considered as problems faced by respondents to the use of Internet facilities are; lack of Internet facilities LIF $\left(.905^{\star *}\right)$, inadequate network IANW $\left(.926^{\star *}\right)$, lack of power supply LOPS $\left(.333^{* \star}\right)$, distance to cybercafé DCC $\left(.913^{\star \star}\right)$ and long queues at the cybercafé LQACC $\left(.747^{\star \star}\right)$.

During the interview, only $35.80 \%$ respondents stated that lack of awareness of existence of Internet facility was a problem in their use of Internet facilities. This means that, majority of the respondents were aware of the existence of Internet facilities and were willing to communicate through it. In the same vein, poverty of users is a socioeconomic factor but it is not significant because of its low loading. 
These ratings are somewhat consistent with the findings of NITDA (2003), where slow Internet development in Nigeria was attributed to lack of skills/knowledge, high cost of computers and reliable power supply.

Table 3: Factor analysis of problems faced by farmers and extension workers in the use of internet facilities

\begin{tabular}{llll}
\hline $\mathbf{S} / \mathbf{N}$ & Variable & ${ }^{*}$ Factor 1 & ${ }^{* \star}$ Factor 2 \\
\hline 1 & LAEI & .276 & $.932^{\star *}$ \\
2 & LIF & $.364003 \mathrm{E}$ & $.905^{\star \star}$ \\
3 & HCOC & $.905^{\star}$ & $.36400 \mathrm{E}$ \\
4 & HCOAT & $.881^{\star}$ & $.389003 \mathrm{E}$ \\
5 & LOSK & $.854^{*}$ & .210 \\
6 & IANW & .296 & $.926^{\star *}$ \\
7 & PAROE & .214 & $.905^{\star *}$ \\
8 & LOPS & $.920003 \mathrm{E}$ & $.333^{\star *}$ \\
9 & DCC & .259 & $.913^{\star *}$ \\
10 & LQACC & $.515003 \mathrm{E}$ & $.747^{\star *}$ \\
11 & PAVOU & $.900003 \mathrm{E}$ & $.340^{\star *}$ \\
\hline
\end{tabular}

Source: Derived From: Field Survey Data, 2012.

Rotation Method: Varimax with Kaiser Normalization

*Factor 1: Socio-economic factors

${ }^{* *}$ Factor 2: Infrastructural factors

\section{Conclusion}

Based on the result of the study, the following conclusions are made.

Respondents were mostly youth who were exposed to so many ICT facilities in their localities with radio been the most common (100.00\%) which was followed by GSM facilities (96.40\%). Though, some respondents had used the Internet for one reason or the other, they were faced with so many problems which included lack of skills and knowledge, distance to the cybercafé and inadequate network.

\section{Recommendation}

Based on the findings of this study, the following recommendations are made;

1. There is the need for the three tiers of government to put in place a legal and institutional framework which enhances a full take off of the Internet usage in the agricultural sector especially among farmers and extension workers.

2. Establishment of Internet centres: there is the need for the establishment of Internet centres in the rural areas. Such Internet centers will necessarily need to be equipped with computer hard ware, operating system, soft ware, laptop and moderns. All these should be powered by car batteries or solar panels which should also be provided.

3. Internet Education: The rural farmers and extension workers should be trained on the basic Internet knowledge and skills. 


\section{References}

Agbarevo, M.N (2007): the influence of Gender on the adoption of agricultural extension recommendations by resource-poor men and women farmers in cross river state. Journal of research in agricultural Vol.3No1,p 69.

Alao, J.A. (1980): Understanding Small Farmer Adoption Behavior: The Nigerian Experience. Inaugural Lecture Series, No. 44, University of Ife Press, P.1

Arokoyo, T. (2008): The use of ICTs in Nigeria's Agricultural Extension Service. In: Ogungbameru, B.O. Undiandeye, C.U and Ani, A.O (Eds.): Agricultural extension Methodologies. Apani Publishers, Kaduna, pp 136-146.

Ayichi, D. (1995): Agricultural Technology Transfer for Sustainable Rural Development. In: Eboh, E. C., Okoye, C. U. and Ayichi, D. (Eds.): Rural Development in Nigeria; Concepts, Processes and Prospects. Auto-Century Publishing Company. P131.

Benue State Gov't (2012): Benue State Government Diary, Produced by Benue State Ministry of Information and Orientation, Makurdi.

Gazette (2009): Federal Republic of Nigeria, Vol.96, No. 2 Abuja.

Gyata, B. A. and Obinne, C. P. O. (2012): Effects of Climate Change on Food Security Status of Rural Farmers in Nigeria. A Paper Presented at the $17^{\text {th }}$ Annual National Conference of AESON, University of Nigeria Nsuka Nigeria, $13^{\text {th }}$ March Pp11.

National Information Technology Development Agency (2003): "ICT Baseline Study" www.nitda.gov.ng retrieved $17^{\text {th }}$ May, 2010 .

Odiaka, E.C. (2011): Contributions of Information and Communication Technology (ICT) To Rural Development in Nigeria. In: Nwachukwu, I. and Ekwe, K. C. (Eds.). Globalization and Rural Development in Nigeria. Extension Centre, Michael Okpara University of Agriculture, Umudike. Pp 373-383.

Ogunbameru, B.O; Udiandeye, U.C and Ani, A.O (2008): Definitions, Philosophy and Principles of Agricultural Extension. In: Ogunbameru, B.O.; Undiadeye, U.C and Ani, A.O. (Eds.): Agricultural Extension Methodologies. Apani Publications, Kaduna, 1-12 pp.

Rodriguez, F. and Wilson, E. (2000): "Are Poor Countries Losing the Information Revolution?"InfoDev Working Paper, Washington D. C. World Bank. 